\title{
BULLYING NA ESCOLA: UMA REVISÃO LITERÁRIA
}

\section{José Lindemberg Bernardo da Silva, Universidade Federal de Campina (UFCG),} bergbernardo.s@gmail.com

Eridiany Bezerra Gomes, Universidade Federal de Campina Grande (UFCG), eridiany_tf@hotmail.com;

Isaac de Souza Lima isaacsabu@hotmail.com

\section{RESUMO}

O trabalho aborda conceitos contemporâneos sobre o Bullying na Escola, a partir disto temos como objetivo principal a discussão de problemas causados no processo de ensino-aprendizagem, sendo um fator para a causa do alto nível de evasão nas escolas. A metodologia utilizada, foi uma revisão literária de caráter qualitativa e documental, também através de pesquisa de artigos acadêmicos que tratasse acerca do tema exposto. Verificou-se que o bullying está associado, em parte, a preconceitos sociais, a dificuldades decorrentes da formação moral/ética/cidadã de personalidades ligadas à fragilidade de modelos sociais encontrados no âmbito familiar e social. A pesquisa empírica revelou que o bullying é um dos principais fatores para a causa da evasão escolar, contudo, existe a despreparação do professor para enfrentar este problema escolar, isto torna a ser um dos papéis do professor no mundo contemporâneo, que é lidar e mediar relações que causem o desequilíbrio harmônico do ambiente escolar, utilizando metodologias ativas que busca a integralidade escolar embasada no processo de respeito mútuo, causando um melhor desempenho escolar. Portanto, conclui-se que o bullying é um problema gravíssimo encontrado no meio escolar, todavia, vemos que deve existir uma interligação entre escola/família/sociedade, buscando métodos que possibilite a amenização deste problema.

PALAVRAS-CHAVE: Bullying; Escola; Reflexão.

\section{REFERÊNCIAS}


ALVES, M. G. Viver na escola: indisciplina, violência e bullying como desafio educacional. SciElo, 2016.

http://www.scielo.br/scielo.php?script=sci_arttext\&pid=S010015742016000300594\&lang=pt $>$ Acesso em 23 de Abril de 2017.

CAVANÊZ, F. A escola na contemporaneidade: uma análise crítica do bullying. SciElo, 2015.

FERREIRA, J. M. e TAVARES, H. M. Bullying no ambiente escolar. Revista da Universidade Católica, Uberlândia, v. 1, n. 2. 2009.

PAIXÃO, G. P. N. et al. Violência escolar: percepções de adolescentes. Revista Cuidarte, 2014.

SANTOS, M. M. et al. Bullying: atitudes, consequências e medidas preventivas na percepção de professores e alunos do ensino fundamental. Pepsic, 2015. < http://pepsic.bvsalud.org/scielo.php?script=sci_arttext\&pid=S1413-

389X2015000400017\&lng=pt\&nrm=i\&tlng=pt > Acesso em 22 de Abril de 2017. 